\title{
BIBLICAL SPIRITUALITY, THE PSALMS, AND IDENTIFICATION WITH THE SUFFERING OF THE POOR:
A CONTRIBUTION TO THE RECENT AFRICAN DISCUSSION ON PSALM $109^{1}$

\author{
Christo Lombaard \\ Christian Spirituality \\ University of South Africa
}

\begin{abstract}
The discipline of Biblical Spirituality makes again explicit what has at times remained only implicit or has at times been overlooked in exegetical practice: that the biblical texts face two ways. On the one hand, the faith-in-historical-context which lead to the biblical texts being created, and on the other hand, the faith-inhistorical-context from which these texts have been/are being read, are both important to the discipline of Biblical Spirituality. The Psalms have played a particularly significant role throughout the respective histories of both lived biblical spiritualities and studies in the field of Biblical Spirituality. Specifically as it relates to the suffering of the poor, special attention is paid to Psalm 109: two recent African studies on this Psalm are taken into review, and drawing on all of the above, a new proposal is made for understanding verses 6-20.
\end{abstract}

Key Words: Biblical Spirituality, Spirituality and the Psalms, African Bible Interpretations, Psalm 109

\section{'The Question is: What made Him read the Bible?'}

In Bruce Chatwin's South American travel account In Patagonia, the author quotes someone he encountered discussing the suicide of an acquaintance. The off-hand remark that Chatwin relays carries two opposing insights. On the one hand, it conveys fiercer criticism of the Bible than any of the currently popular missionary atheists (e.g. Hitchens 2007, Dawkins 2006, Harris 2004) express. Paradoxically, at the same time, it shows on the other hand a deeper spiritual sensitivity than much currently popular spiritual literature (from novelist Paulo Coelho's arrogant spirituality in e.g. The Zahir, 2007, to Byrne's 2007 The Secret, a superficial pop spirituality publishing sensation, to name just two instances) can hope to convey. Chatwin (1977:185) namely quotes his associate as saying:

“"José Macías had been reading the Bible and the Bible is a book that makes men mad. The question is: What made him read the Bible?"”

Previous versions of this paper were presented at the Pro Psalms 'Psalmody and Suffering' seminar, 25-26 August 2011, Faculty of Theology, University of Pretoria, at the departmental research seminar, Department of Christian Spirituality, Church History and Missiology, University of South Africa, 13-14 September 2011, and at the Spirituality Association of South Africa's Prayer as a Spiritual Practice conference, 4 November 2011, held at the University of South Africa. 
These two sentences convey accurately the two faces of the academic discipline of Biblical Spirituality. This includes, on the one side, the confounding historical, exegetical, hermeneutical and theological aspects to the biblical texts. On the other side, at the same time, Biblical Spirituality encompasses the mystifying, even mysterious religious, existential attraction to this Text. Is it a case of moths to a flame? Or is it rather life seeking light?

The metaphors preferred to describe this conundrum of 'Bible-and/versus-reader' will depend on whomever makes the observation. The task Biblical Spirituality has set itself is to study in multi-disciplinary ways (cf. Lombaard 2011a) the interaction with the texts, both as the texts went through their respective formation processes and as believers later engaged - in disparate ways - with the canonised texts, but then also to analyse critically various observers' stances on these dynamics (cf. e.g. the studies collected in Lombaard 2011b). Biblical Spirituality as a scholarly field thus seeks to combine exegetical engagement with the texts of Scripture, endeavouring to understand along with all the usual exegetical interests also the faith dynamics at work behind them (cf. e.g. Barton 1992; see the triangular model developed to portray these interests in Lombaard 2011c), with the transformative experiences of the readers of these texts (Waaijman 2002:426-481). This interest in interaction between text and reader/listener (cf. Dingemans 1991) is of course nothing new in the Judeo-Christian religious history: as difficult as it is to sustain a strict separation of 'exegesis' and 'application' when engaging with a biblical text (Le Roux 1997:410-416; cf. Barnard 2004:5), this broad idea had indeed been part of the practice of biblical spirituality (i.e. faith in direct dialogue with a biblical text) ${ }^{2}$ since its inception in Nehemiah 8 (cf. Lombaard 2011a). Interpreting the biblical text while at the same time being interpreted by it, was part of much of the exegetical and scholarly agendas throughout the modern era (although it had for various reasons not always been experienced as such). This two-way interpretative street had also been implicitly a part of the engagement of 'ordinary readers' (to employ the terminology of e.g. West 1995 in this regard) with the Scriptures throughout the almost two and a half millennia in the wake of Nehemiah 8.

In the history and the liturgy of the church, among the Old Testament literatures (cf. however, Lombaard 2003:433-450) the Psalms have held a particular pride of place in this regard (as attested to again by the title of Human \& Vos 2004).

\section{The Psalms in Biblical Spirituality}

The reasons given for the relative popularity of the Psalms in the church and among the faithful in their personal devotions are both varied and well known. The most common of these is the breadth of human experience covered in these 150 poems/songs, so that it becomes possible for readers to identify within that collection well-nigh any current life situation or mood they experience (cf. Vos 2005:19-49). However, there is more to this than such an affirming identification of parallel experiences or emotions. McConville (2011) namely notes that, in a certain way, the Psalms also do what they say: in the act of calling forth a certain reaction by the reader, the Psalm itself enacts that deed. As in its language a Psalm may ask of the reader to adopt a certain stance (of praise or lamentation, for instance), the text-reader interaction already elicits that response from the reader. This is not only 'waiting for meaning' from a Psalm (Barnard 2004:1-10); this interactivity, so

Spelt with capital letters, 'Biblical Spirituality' refers to the academic discipline; spelt 'biblical spirituality', the reference is to piety practiced in relation to Scripture. 
important for the discipline of Biblical Spirituality, ${ }^{3}$ is at once also guided by, exemplified within the text itself.

Naturally, this is not only true of the Psalms, or it is true in different ways of the other biblical literatures too. However, in history the Psalms have played a more substantial role in these dynamics, as mentioned above. This is reflected also in the recent books that have been published on specifically the spirituality of the Psalms: Carroll Stuhlmueller's The spirituality of the Psalms and Walter Brueggemann's Spirituality of the Psalms, both from 2002, Kees Waaijman's Mystiek in de psalmen of two years later, and David Firth's 2005 Hear, o Lord. A spirituality of the Psalms (for a discussion of these works, see Lombaard 2006a:909-929). Although these works differ in orientation, from a more historical inclination to more thematic approaches to a mystical focus, and though all four books reflect their authors' personal and ecclesial backgrounds in certain ways, they do have this denominator in common: that they seek to facilitate an interaction with the Psalms in which the readers not only know something about the individual books and (reflecting also the newer trend in research - cf. Zenger 2006:351-354) the collection as a whole, but that they also experience something (cf. Wildman 2011:1-30) from the Psalms. Not only the mind, but also the spirit must be enlightened. Meaning is in this mode of reading the Psalms not less intellectual, but is also more experiential - in the usual language of the Spirituality discipline: transformative. God knows, God must be sensed too. It is this particular perspective which, as will become clear below, can open up new exegetical insight.

A good way to give greater perspective on this explicitly religious dimension of engaging with a biblical text would be, as stated above, "to analyse critically various observers' stances" on a certain psalm. Psalm 109 proves to be a convenient instance, for three reasons:

- It has been a recent focus of analysis by African scholars;

- This focus is limited to two articles, a manageable scope within the limitations of this paper, but then, importantly: two very different articles;

- The Psalm itself contains some elements that are challenging to common religious sensitivities (to the point that Maré 2001:341-351 could easily have asked of this Psalm too whether it is an 'un-Christian' Psalm).

\section{Psalm 109: Two African Readings}

The basic introductory, structural and theological questions related to the $109^{\text {th }}$ Psalm are largely agreed upon (cf. e.g. Leuenberger 2004:287; Weber 2003:215-220; Allen 2002:96107; Davidson 1998:358-363; Mays 1994:348-350; Wright 1994:392-402; Gunkel 1986 [1929]:475-480; Brueggemann 1985:144-154; cf. Zenger 2006:354-356). Quite possibly post-exilic, this is an individual Psalm of lament, of a strongly imprecatory character (cf. Laney 1981:35-36), which based on the change from plural to the singular and then again back to the plural when referring to the enemy, is straightforwardly dividable into three broad sections: verses 1-5, 6-20, and 21-31 (with sub-divisions possible). Whereas the opening and closing sections of the Psalm contain fairly straightforward lament, which seems to have wide pastoral applicability, the 'key issue' (Davidson 1998:359; cf. Firth 1996:317-328) of the harsh wishes on the enemy in the middle section (similar to for instance the conclusion to Psalm 137) create various ethical and religious problems (cf. e.g.

McConville 2011 relates this perfomativity to Waaijman 2002:713, but it also, perhaps unintentionally, parallels a traditional Christian dogmatological understanding of the person and work of Christ, namely that He is what He proclaims (namely salvation). 
Day 2002:166-186). Some scholars have over recent years tried to solve the problem by proposing that the middle section be viewed as a quote relaying the enemy's wishes on the individual supplicant who expresses his malaise in the surrounding sections of the Psalm (cf. summary in Zenger 1996:59-60). These harshly negative expressions are therefore for the enemy's account, thus eluding the difficulty of engaging with a difficult theological problem (for this Psalm, at least). Most scholars, though, do not follow this suggestion, leaving the way in which to treat such harsh sentiments (cf., as a parallel, Lombaard 1999:139-141) as the major interpretative issue with Psalm 109.

Two Africans have recently each published quite different takes on this Psalm to the usual issues engaged with by scholars. David Adamo and Eben Scheffler ${ }^{4}$ have namely proposed ideologically-critical readings of Psalm 109, both of whom in doing so interpret and appropriate this text contextually; however, they do so in quite different ways:

- Adamo (2008:575-592) namely follows the standard approach of his generation of Bible scholars who wish to affirm their African identity by setting up their work over against so-called Eurocentric exegesis. ${ }^{5}$ The point is made forcefully by Adamo that Western interpretations do not speak to the context, nor to the heart, of African Bible readers. What would be required, is a deliberately differently-localised cultural hermeneutics (cf. e.g. Adamo 2001). This specific orientation towards some aspects of traditional African cultures indeed enables Adamo to propose a new understanding of the middle section (verses 6-20) of Psalm 109, which he understands as part of the narration of the same supplicant as in the rest of the Psalm. The enemy addressed in these verses is namely not a human party, according to Adamo, but are rather destructive aspects of life, which could include illness and poverty and evil, thus rendering the curse in these verses far less disturbing than it usually sounds to Western ears. Not individuals, but that which is harmful in life is condemned in these verses (this view comes close to that expressed by Dhanaraj 1992). ${ }^{6}$ By reciting such curses against these destructive aspects of life, African believers will experience themselves protected from these forces, Adamo indicates. The implication is left, though not made with strong argumentation by Adamo, that this may have been how these verses were understood in ancient Israel too. Nothing destructive ought therefore to be done against actual human beings, according to these verses thus understood. Such actions (namely of retribution for perpetrating evil

$4 \quad$ I know both these scholars personally, from informal conversations, listening to them presenting and discussing conference papers, and reading their publications. This of course adds different dimensions, of perhaps slightly too sympathetic a nature, to my brief descriptions of their work here.

5 This is an interpretative approach and a scholarly stance of which I am, broadly, critical (cf. Lombaard 2009:274-287 \& 2006b:144-155), because: it is based on a false juxtapositioning of 'the West' and 'Africa' (so too again, very recently, Du Preez 2011); it can very easily become one-sided and too loyally uncritical (so too Høyland 1998:56); it takes Old Testament scholars away from their key competencies, to venture into fields we are academically unprepared for, and thus does the own discipline and, often, therefore also the cross-disciplinary enterprise a disservice; lastly, even though over at least the last three decades incessant calls have been made by African scholars of different races for such inherently African methodologies - no study has yet been forthcoming which could be presented as intrinsically African and non-Western. (The single exception may be the unsatisfying situation that the only characteristic trend of African Bible scholarship would be its recurring calls for a characteristic African Bible scholarship.) The reason for this brings us back to the first of these four objections listed here: scholarship simply cannot be inherently insular.

Yet, these objections do not mean that interpretative possibilities gained from such hermeneutics are without exegetical value. As seen below with Adamo, he in fact comes to a viable new possibility, but then and this too is often found with such African-hermeneutical analyses - he does not explicitly seek to plow back such insights into the text.

6 My thanks to E Otto for pointing this out. There is, however, no evidence of this source having been available to Adamo, which means we probably here have an instance of independent proposals developing in parallel. 
deeds), Adamo points out, must be left to God (cf. e.g. Brueggemann 1985:147 for the diametrically opposed view).

- Scheffler (2011:192-207), on his part, continues his research focus over the past two decades with its strong sympathies towards the marginalised of society (cf. e.g. Scheffler 1993), by investigating the rhetorics on poverty in Psalm 109. His introductory overview is textual, namely of the different views on the poor encountered in the Psalter, upon which he offers a detailed analysis of this specific Psalm. God's justice/steadfast love vis-à-vis the 'poor and needy' (cf. e.g. Mays 1994:349; Barré 1986:100-105; Brueggemann 1985:149-151) stands central. On the controversial middle section of Psalm 109, Scheffler rejects the transposing of these words to the mouth of the enemy on the grounds that verse 20 indicates that the supplicant anyway identifies with the harsh sentiments expressed in the preceding verses. The problem thus does not go away. What is more, Scheffler indicates strongly that nowhere in the Psalms on poverty are the direct voices of the poor heard; at best, pleading on behalf of the poor is found, namely by an educated elite. In Psalm 109, however, yet more radically, the supplicant - a member of this elite - identifies with the poor not for their sake, but for his own. The poor are thus used rhetorically, in the face of the intended audience and God, in the hope of the supplicant himself benefitting directly from such association. This - Scheffler indicates in an all too brief conclusion - parallels precisely the tactics of some powerful members of the elite on the current South African political and societal spectrum.

\section{In Comparison}

On the face of it, these two divergent new expositions of Psalm 109 seem to have little in common. Indeed, they are quite different, and these differences are both important and healthy for the sake of the scholarly study of the text concerned, and for the possible implications this could have for a modern readership. Competing findings preclude intellectual mediocrity. However, on closer examination, Adamo and Scheffler are not 'completely different' (Barnard 2004:11) from one another, at least in certain respects:

- Both authors draw directly on their observations of the biblical text concerned and their awarenesses of important problems in their African contexts;

- In doing so, both come to a novel insight on the possible meaning that this Psalm had in its ancient context;

- At the same time, though in a different order (Adamo starts with his context, and then seeks to appropriate the text to it; Scheffler starts with the text, and then indicates appropriate applicability), Psalm 109 is brought into dialogue with the society in which the author lives;

- In their analyses, the authors draw strongly on insights of other scholars with which they engage critically in order to:

- come to an own, informed, yet independently formed view which is put forward and defended - inherently a very Western intellectual exercise,

- apply these insights to a cause in society which is perceived as existentially important, in such a direct way that modern European scholars would have great difficulty to emulate such an indication of almost immediate relevance, and in doing so, our two authors exhibit a distinct trait of current African Christianity;

- Most tellingly from the vantage point of the discipline of Biblical Spirituality, and important for the insight arrived at below: with both writers, there is not an explicitly stated, but an implicit, almost behind-the-scenes (theologically formed) awareness of 
the presence of God, somehow, related to the call they make, respectively for Africanisation and against the exploitation of the poor. The way they would verbalise their underlying theological conceptions would be very different, to be sure; yet, the fact that this awareness is there, palpable in their writing, remains. This kind of 'there - not there' God awareness is, moreover, nothing strange to the Psalter (Doyle 2010:377-390), also in different ways.

It is on this last point that is built forth in the conclusion.

\section{Psalm 109: A Proposal}

The two African scholars' insights on Psalm 109 briefly analysed above includes the sense gained that, although one cannot escape the awareness that they perceive their insights as theologically informed and important, their God-talk is by implication. God is not directly spoken of, nor addressed. This is characteristic of much of modern Bible scholarship. The discipline of Biblical Spirituality, however, would seek such dimensions deliberately. This does not mean that one has to forego either detailed textual work or a real contextual involvement, as is at times suspected of the discipline of Spirituality. However, as essentially valid as the historical given of, amongst other factors, the relationship between the authorial verbum cordis (cf. the application of le Roux 2004:123-130 to the Psalms, and more generally, Arens 1980:13-27 on this Augustinian concept in De trinitate) and the resultant text is, and as valid as the contextual hermeneutical appropriation of the resultant text within the receiving context is (cf. Lombard 1999:353-368), there is more. For most readers of the Bible, including many (most?) scholars, there is always a sensed presence, implicit yet inescapable, of God (cf. again the triangular model in Lombaard 2011c).

This too can inform directly our understanding of Psalm 109.

The religious piety of the supplicant in the opening and closing sections of Psalm 109 stand above board: to place one's troubles and personal suffering in front of God, is in all healthy spiritualities both accepted and encouraged, namely as an act of faith and trust, in humility. Less accepted, though, in broad religious circles, is also to bare to God one's negative emotions, the harshest of the inner experiences we have as humans. The question that may be asked, is: is this not perhaps precisely what is happening in Psalm 109:6-20?

In such a psycho-pastoral interpretation, we find in the middle section of Psalm 109 the individual supplicant expressing in brutal honesty the severest of emotions he experiences against those whom he regards as his persecutors. The sheer hatred is not shied away from in these words; in fact, it is laid out clearly, in shocking, violent detail. Very importantly, the addressee of these experiences is the Divine. It is to God that these urges are declared.

This direct God-talk may hold the key to understanding the violence expressed here. There is namely no expectation that either the supplicant or God would in fact act out these dark visions. The act is, rather, the prayer. In the relation with the Divine, these in/human urges can be given voice to, and in fact are, namely as an act of faith. Already Gunkel (1986 [1929]:476) hints in this direction, when he writes in his opening sentence on this Psalm that 109 is "(e)ine furchtbarer Fluchpsalm ... in denen sich eine wilde Phantasie austobt". Not the enactment of the actions proposed in the prayer is the purpose here. The pastoral purpose has already been fulfilled in voicing these dark wishes coram Deo.

This would leave verse $4 b$ as a key verse of Psalm 109: 


\begin{tabular}{|c|c|c|c|}
\hline Psalm 109:4b & Literal translation & Dynamic translation & Free translation \\
\hline 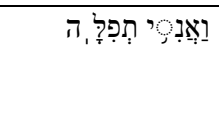 & $\begin{array}{l}\text { But I, I am a man-at- } \\
\text { prayer }\end{array}$ & $\begin{array}{l}\text { Yet I am someone who } \\
\text { prays }\end{array}$ & $\begin{array}{l}\text { As for me, I am a } \\
\text { someone who prays } \\
\text { (to solve my problems) }\end{array}$ \\
\hline
\end{tabular}

Although such a directly God-oriented pastoral dénouement may fit poorly with many popular pieties of our time, the personal religious and psychological value is clear. As Brueggemann (1985:152, though not in building an argument similar to that here) has written on this matter:

Instead of a dismissal of such a prayer, we may take note that this Psalm models what to do with such negative destructive yearnings ... The theological problem with such ways of handling these feelings is that such a sense of injustice in fact does concern Yahweh... The throne of Yahweh is indeed the place for such complaint and petition. ${ }^{7}$

If this interpretative possibility is indeed valid, it changes what had always seemed to be one of the most unsavoury passages in the Psalms into perhaps one of the most valuable ${ }^{8}$. There may be much madness about in humanity, but perhaps that is just one more reason to read passages such as Psalm 109 in the Bible.

\section{BIBLIOGRAPHY}

Adamo, D 2008. Reading Psalm 109 in African Christianity. Old Testament Essays 21/3, 575-592.

Adamo, D 2001. Reading and interpreting the Bible in African Indigenous Churches. Eugene: Wipf \& Stock.

Allen, LC 2002. Psalms 101-150 (Word Biblical Commentary 21). Nashville: Thomas Nelson Publishers.

Arens, H 1980. 'Verbum Cordis': Zur Sprachphilosophie des Mittelalters. Historiographia Linguistica 7:1/2, 13-27.

Augustinus, A 1968. De trinitate. Corpus Christianorum, Corpus Latina, 50-50A. Turnhout: Typographi Brepols Editores Pontificii.

Barnard, M 2004. Waiting for meaning - Psalms in cult and culture, in Human, DJ \& Vos, CJA (eds) Psalms and Liturgy. New York: T\&T Clark International, 1-14.

Barré, ML 1986. The formulaic pair țwb (w)hsd in the Psalter. Zeitschrift für die alttestamentliche Wissenschaft 98/1, 100-105.

Barton, SC 1992. The spirituality of the gospels. London: SPCK.

Brueggemann, W 2002. Spirituality of the Psalms. Minneapolis: Fortress Press.

Pastoral use of these insights would be best suited for interpersonal, one-on-one, counselling situations. In a public or group setting, room for misunderstanding or misappropriation of these verses would be large.

8 This insight, though, is presented for this Psalm only, and is not meant to be extrapolated to all other instances in which violent or otherwise disturbing language and imagery are found in the Psalms, in the Old Testament or in the Bible as a whole. The proposed insight is thus not meant to solve the problem of morally reprehensible language as it is brought into relation with God in the Bible; its intended applicability is limited to Psalm 109. 
Brueggemann, W 1985. Psalm 109: Three times 'Steadfast Love'. Word \& World V/2, 144-154.

Byrne, R 2006. The Secret. New York: Atria Books.

Chatwin, B 1977. In Patagonia. London: Jonathan Cape.

Coelho, P 2005. The Zahir. London: HarperCollins.

Davidson, R 1998. The vitality of worship. A commentary on the book of Psalms. Grand Rapids; William B Eerdmans.

Dawkins, R 2006. The God delusion. London: Bantam Press.

Day, JN 2002. The imprecatory Psalms and Christian ethics. Bibliotheca Sacra 159, 166-186.

Dhanaraj, D 1992. Theological significance of the motif of enemies in selected psalms of individual lament. Glückstadt: Augustin.

Dingemans, GDJ 1999. Als hoorder onder de hoorders: hermeneutische homiletiek. Kampen: Kok.

Doyle, B 2010. Where is God when you need him most? The divine metaphor of absence and presence as a binding element in the composition of the Book of Psalms, Zenger, E (ed.) The composition of the book of Psalms (Bibliotheca Ephemeridum Theologicarum Lovaniensium 238). Leuven: Uitgeverij Peeters, 377-390.

Du Preez, M 2011. The South African dream is far from dead (Van Zyl Slabbert Memorial Lecture, 24 August 2011, Polokwane). www.facebook.com/notes/max-du-preez/thesouth-african-dream-is-far-from-dead-van-zyl-slabbert-memorial-lecture-byma/199160013480656 [accessed 25 Aug. 2011.)

Firth, DG 2005. Hear, o Lord. A spirituality of the Psalms. Calver: Cliff College Publishing.

Firth, DG 1996. Responses to violence in some lament Psalms of the individual. Skrif en Kerk 17/2, 317-328.

Gunkel, H 1986 [1929]. Die Psalmen. Göttingen: Vandenhoeck \& Ruprecht.

Harris, S 2004. The end of faith. Religion, terror, and the future of reason. New York: WW Norton \& Co.

Hitchens, C 2007. God is not great. How religion poisons everything. New York: Twelve.

Høyland, M 1998. An African presence in the Old Testament? David Tuesday Adamo's interpretation of the Old Testament Cush passages. Old Testament Essays 11/1, 50-58.

Human, DJ \& Vos, CJA (eds) 2004. Psalms and liturgy. New York: T\&T Clark International.

Laney, JC 1981 A fresh look at the imprecatory Psalms. Bibliotheca Sacra 138, 35-45.

Le Roux, JH 2004. Augustine, Gadamer and the Psalms (or: the Psalms as the answer to a question), in Human, DJ \& Vos, CJA (eds) Psalms and liturgy. New York: T\&T Clark International, 123-130.

Le Roux, JH 1997. Our historical heritage. Old Testament Essays 10/3, 401-423.

Leuenberger, M 2004. Konzeptionen des Königtums Gottes im Psalter. Zürich: Theologischer Verlag Zürich.

Lombaard, C 2011a. Biblical Spirituality and interdisciplinarity. Paper read at conference: "Claiming Conceptual Space. Reimagining the Study of Religion and Theology: Changing Contexts and Social Discourses", Huguenot College, Wellington, 6-10. April 2010. Publication forthcoming: Religion \& Theology 2011. 
Lombaard, C 2011b. The Old Testament and Christian Spirituality. Collected methodological essays. South African and general perspectives. Atlanta: Society for Biblical Literature.

Lombaard, C 2011c. Pentateuch theory and Biblical Spirituality. Invited guest lecture, St. Edward's University, Austin, Texas, USA, 14 October 2010 (via Skype). Publication forthcoming: HTS Theological Studies 2011.

Lombaard, C 2009. Does contextual exegesis require an affirming Bible? Lessons from 'apartheid' and 'Africa' as narcissistic hermeneutical keys. Scriptura 101, 274-287.

Lombaard, C 2006a. Four recent books on spirituality and the Psalms: some contextualising, analytical and evaluative remarks. Verbum et Ecclesia 27/3, 909-929.

Lombaard, C 2006b. The relevance of Old Testament science in/for Africa: two false pieties and focussed scholarship. Old Testament Essays 19/1, 144-155.

Lombaard, C 2003. The Old Testament in Christian spirituality: perspectives on the undervaluation of the Old Testament in Christian spirituality. HTS Theological Studies 59/2, 433-450.

Lombaard, C 1999. Even the worst of times (Psalm 137), Maseru Anglican Cathedral. The T.E.E. Journal (Volume theme: Experiments in contextualization and globalization) 3, 139-141.

Lombard, C 1999. Inculturation and ecumenism, in Lombaard, C (ed). Essays and exercises in ecumenism. Pietermaritzburg: Cluster Publications, 353-368.

Maré, LP 2011. Psalm 137: 'n (On)Christelike Psalm? Verbum et Ecclesia 22/2, 341-351.

Mays, JL 1994. Psalms (Interpretation). Louisville: John Knox Press.

McConville, G 2011. Happiness in the Psalms. Acta Theologica 2011 (forthcoming).

Sheffler, EH 2011. Pleading poverty (or identifying with the poor for selfish reasons): on the ideology of Psalm 109. Old Testament Essays 24/1, 192-207.

Scheffler, EH 1993. Suffering in Luke's Gospel. Zürich: Theologischer Verlag.

Stuhlmueller, C 2002. The spirituality of the Psalms. Collegeville, Minnesota: Liturgical Press.

Vos, CJA 2005. Theopoetry of the Psalms. Pretoria: Protea Book House.

Waaijman, K 2004. Mystiek in de psalmen. Baarn: Uitgeverij Ten Have.

Waaijman K 2002. Spirituality: Forms, Foundations, Methods. Leuven: Peeters.

Weber, B 2003. Werkbuch Psalmen II. Die Psalmen 73-150. Stuttgart: Verlag W Kohlhammer.

West, G 1995. Biblical hermeneutics of liberation. Modes of reading the Bible in the South African context ( $2^{\text {nd }}$ ed.). Maryknoll: Orbis Books.

Wildman, WL 2011. Religious and spiritual experiences. Cambridge: Cambridge University Press.

Wright, DP 1994. Ritual analogy in Psalm 109. Journal of Biblical Literature 113/3, 385-404.

Zenger, E (Hg.) 2006. Einleitung in das Alte Tesament (6. Auflage). Stuttgart: Verlag W Kohlhammer.

Zenger, E 1996. A God of vengeance? Understanding the Psalms of divine wrath. Louisville: Westminster John Knox Press. 